\title{
The political ecology of climate adaptation assistance: Alaska Natives, displacement, and relocation
}

\author{
Christine Shearer ${ }^{1}$ \\ University of California at Santa Barbara, USA
}

\section{Introduction}

The Native Village of Kivalina lies approximately eighty miles north of the Arctic Circle, on the tip of a thin, six-mile long barrier reef island of 27 acres (11 hectares). Its population of about 400 is primarily Inupiat, part of the Inuit populations of native Arctic people. In 1992, Kivalina residents voted to relocate their entire community, primarily because of the steady erosion of their island-a decision later backed by a 2003 U.S. Government Accountability Office report surveying the effect of climate change on Alaska Native villages, as well as a 2006 Army Corps of Engineers report. Yet two decades later, Kivalina is still seeking relocation, despite consistent meetings and petitioning of U.S. government and Alaska Native tribal bodies and representatives. Indeed, while many government agencies have worked within their prescribed parameters to try and assist Kivalina, the progress toward resettlement has been negligible. This is potentially dangerous, given that the village is situated between a sea and a lagoon, and has only limited means for evacuation from big storms, which are increasingly affecting and eroding the tiny island.

Social researchers have argued that addressing social problems requires first recognizing, defining, and establishing ownership over the problem (Gusfield 1989). Internationally, the problem of climate change is being defined in ways that may unintentionally eclipse the problems facing communities like Kivalina. UN international reports are noting inter-national inequalities in responsibility for global warming and the distribution of its impacts (UNDP 2007), primarily caused by historic emissions from industrialized countries and countries in transition categorized as Annex I and Annex II, and disproportionately impacting countries categorized as 'developing'-mirroring the already unequal international distribution of wealth and resources (Bierbaum et al. 2007). While noting inter-national inequities in the contribution to overall greenhouse gas emissions and impact is arguably necessary for assessing differing levels of responsibility and need (Agarwal and Narain 1991; Roberts 2001), it can have the unintentional effect of masking intranational inequality (Shearer 2011), and creates barriers to assistance for some communities (Ford 2009). For example, the need for national adaptation programs for action on climate change was agreed under the UN Framework Convention on Climate Change (UNFCCC) process in 2001, but cannot be accessed by Inuit populations like Kivalina, because they are not formal State actors under the agreement and thus not considered party to the Treaties (Budreau and McBean 2007).

This means Kivalina must in many ways look to the U.S. government to represent its interests and needs regarding climate change. But does being located within an industrialized Annex I country ensure adequate adaptation assistance for all residents? This case study of Kivalina suggests it does not, and that the United States can have its own barriers to relocation and adaptation, in ways that are similar and different from countries categorized as 'developing' (Shearer 2011). A transnational analytic framework may therefore help better capture the political, economic, and social factors that can create barriers to climate change adaptation assistance - what could be called the political ecology of adaptation assistance. For example, while communities at risk of displacement in Alaska may have more formal agencies and policies to access, these policies are often insufficient for adequately addressing climate change. Needed policies may also be absent, such as a relocation policy to assist communities facing permanent displacement.

This paper explores some of the barriers to relocation in Alaska through a case study of Kivalina, highlighting the problems faced by both residents and the government agencies trying to assist them. This study suggests that without a clear recognition of, and policy response to, the situation facing Kivalinanamely, displacement from the effects of climate change-government officials tasked with ensuring public safety lack the power to fully assess, mitigate, and address the problem. This has left Kivalina in what is termed here an 'administrative orbit,' with residents made to work their way through a patchwork of various government programs and procedures that are time-consuming and often insufficient. The article highlights the need for relocation policies to assist Alaska Natives, and argues that such policies should be merged with existing ones addressing risk mitigation and disaster management; indeed, disaster management that prioritizes risk mitigation is arguably a bridge to climate change adaptation. A focus on risk mitigation and development of a relocation policy would enable agencies and communities to assess

\footnotetext{
1 Dr Christine Shearer, Post-doctoral scholar, Department of Sociology, University of California at Santa Barbara, USA. Email: cshearer "at" cns.ucsb.edu. I am indebted to the people of Kivalina, government officials, and many researchers who made this study possible. I am also grateful to my family and dissertation committee for their support on this project, particularly John Foran for his wisdom and assistance in helping me travel to Kivalina, my mom for believing in me, and the late William Freudenburg for his invaluable mentorship. Many thanks also to the Eric Wolf Prize committee. All errors and shortcomings within this manuscript are my own. This paper appears in a JPE Special Section of Eric Wolf Prize papers edited by Joe Heyman.
} 
when assets and efforts are better expended on relocation rather than in-situ management of disasters. In addition, I argue for the creation of an adaptation fund through the FCCC available to non-State actors and other vulnerable populations.

\section{Methods}

This article draws from field research in the Alaska Native village of Kivalina in August 2008, some months after it filed a legal claim against twenty-four oil, electricity, and coal companies for their greenhouse gas emissions, exacerbating global warming and the erosion in Kivalina, and seeking damages equivalent to village relocation costs (dismissed and appealed; see Shearer 2011 and Carus 2011). Data includes participant observation and semi-structured interviews. Interviews were conducted with 15 residents of Kivalina: five were members of the Kivalina City Council, and 10 were residents in the community. All identified as Inupiaq, with eight women and seven men. Formal interviews were also conducted with government personnel from various agencies involved in disaster management, infrastructure, and relocation efforts, including the Army Corps of Engineers, the Government Accountability Office, and the Denali Commission, which provides infrastructure support for remote Alaska villages. Interviews were also conducted with workers on the rock revetment project being constructed at the time of the field research.

In addition, data analysis was made of government documents related to Kivalina, and to disaster management and relocation, including those by the Army Corps of Engineers, the Government Accountability Office, the National Oceanic and Atmospheric Administration, and the Alaska Immediate Action Workgroup.

\section{Climate change, adaptation, and dislocation}

\section{The case for "climigration"}

The impacts of climate change are affecting communities unevenly. Climate change exacerbates existing inequalities by increasing the severity and likelihood of extreme weather and disaster events that already heavily affect the world's poor (Raworth 2008). Poverty, and location, are seen as strong, intertwining indicators of vulnerability to climate change, particularly affecting communities with weak or nonexisting municipal governments or lacking other outside forms of assistance (Mearns and Norton 2010a).

To address this imbalance of effects and resources, adaptation efforts are often targeted at increasing community and individual resiliency through strengthened community-based policies and protections, which increase the institutional and personal capacity for communities to draw upon in "adapting" to unavoidable climate change (Kelman 2010; Mearns and Norton 2010b). Scholars and policymakers have noted that the ability to better adapt or survive dangerous climate change is often strengthened through participatory measures and processes that build upon existing community efforts (Mearns and Norton 2010b).

In cases where adaptation is not possible, the result may be community resettlement or forced migration (Warner 2010). At the international level, there have been calls for the category of 'environmental refugee' to be added to existing refugee policies, to assist those temporarily or permanently displaced by ecological changes and environmental disruptions who cannot afford to mitigate the changes (El-Hinnawi 1985). Others argue that refugees and environmental refugees follow different paths: many refugees are escaping persecution from their own government and seeking refuge in another nation, while this is not necessarily the case for environmental refugees, who may be able to migrate within their own nation (Bronen 2009; Morrissey 2012). Thus some have called for a protocol defined specifically for those displaced by climate change_-"climigration"_-established with human rights principles in order to frame the humanitarian response (Bronen 2008). Policies would be set in place to determine when a community no longer needs disaster management, but resettlement (Bronen 2009).

\section{U.S. response to climate change}

In the United States, there has been a concerted political effort to prevent the implementation of regulatory measures for emissions reduction and climate change mitigation. After the U.S. House of Representatives agreed to the international Kyoto Protocol in 1997, the Senate passed the Byrd-Hagel Resolution, stating that it was not the wish of the Senate that the United States be a signatory to Kyoto due to its "unequal treatment of nations," referring to emissions cuts for developing nations that were nonbinding and designed to deal with historic inequities in overall emissions (Roberts and Parks 2006). The Protocol was never ratified by the U.S.

Scholars have noted that, in the run-up to Kyoto, fossil fuel industries and supporters embarked on an expensive public relations campaign to transform growing national understanding and concern over climate change into a non-problem (McCright and Dunlap 2000), creating a political climate conducive toward rejecting Kyoto (McCright and Dunlap 2003).

Efforts to dismiss climate change science and action have helped support pockets of U.S. political resistance to enacting adaptation measures, including community relocation. The uneven effects of climate change are visible and include some rural Alaska Native villages facing the loss of their homelands 
(Shearer 2011). These populations must instead turn toward other government agencies that have not been specifically equipped or empowered, nor sufficiently funded, to deal with climate change and displacement. This includes the Federal Emergency Management Agency (FEMA), tasked with disaster mitigation, preparedness, response, and recovery, and the Army Corps of Engineers (ACE), responsible for investigating, developing, and maintaining the nation's water and related environmental resources, including coastal erosion armament projects.

\section{Disaster management and climate change}

Scholars have noted that the decision-making processes of organizations like FEMA and ACE can heighten public exposure to risk when such institutions are unable to innovate procedures and protocols to address unprecedented problems (March and Olsen 1986). Lacking precedent creates particular difficulties for agencies that rely on established protocols and standardized procedures (Hawkins and Thomas 1989), a process that some have called "retrospective sensemaking" (Weick 1995). Such systems are triggered to action only by institutionally recognized emergencies and disasters, preventing organizational actors from critically reacting to danger signals (Vaughan 2002).

In response to these kinds of problems, there have been calls for more research during the "incubation" period of disasters, concentrating on cases that have the potential for dangerous outcomes (Turner 1976; Turner and Pidgeon 1997; Vaughan 2002). Other studies have focused on events "between crisis and the customary order of things," encompassing "slow motion problems that do not offer clear thresholds or tripping points that activate detection and response," termed crescive troubles (Beamish 2002). Such events evade the institutional triggers of agencies, or the immediate reaction of media that is oriented more towards crises and rapid-onset disasters (Roth 1992). This can lead to mounting "slow motion" problems dealt with through haphazard solutions without comprehensive assessment (March and Olsen 1986), particularly in cases involving unprecedented situations, or in inter-organizational contexts lacking an overarching or centralized structure (Clarke 1999). To minimize these problems, there have been calls for organizations to incorporate trial and error learning, decentralized decision-making, and flexibility of response to be able to innovate new solutions and procedures, particularly during times of uncertainty and potential danger (LaPorte 1996; LaPorte and Consolini 1991).

Similarly, disaster management researchers have suggested a stronger emphasis in U.S. disaster policy on risk mitigation (Christoplos et al. 2001; Pearce 2003). This includes increased public involvement, and a more holistic assessment of problems and solutions (Lavell 1998; Cardona 2003). These calls are taking on a new urgency under climate change, as it has been noted that vulnerable communities are at risk not just from ecological changes, but from insufficient response measures by governments and a lack of policy (O'Brien et al. 2006; Mearns and Norton 2010a). Despite a plea for community-based risk mitigation, in the U.S. the subsuming of FEMA into the Department of Homeland Security in 2002 has helped instead to create disaster management policies prioritizing top-down command and the use of private contractors. Bottom-up community-based risk mitigation procedures receive less attention (Tierney 2003; Gunewardena et al. 2008).

\section{Kivalina}

The Native Village of Kivalina (Figure 1) lies approximately eighty miles $(129 \mathrm{~km})$ north of the Arctic Circle in Alaska, on the tip of a thin, six-mile long barrier reef island of 27 acres (11 hectares) that has diminished in size since the 1950s (Mitchell 2007). Its population of about 400 are primarily Inupiaq, with ancestry to the area going back thousands of years to some of the first settlements in the Americas. The Inupiat credit their survival in the harsh Arctic region to a close understanding of and connection to the cycles and rhythms of the land and sea, and the Inupiaq words for seasons translate literally into their hunting and gathering cycles (Chance 1990).

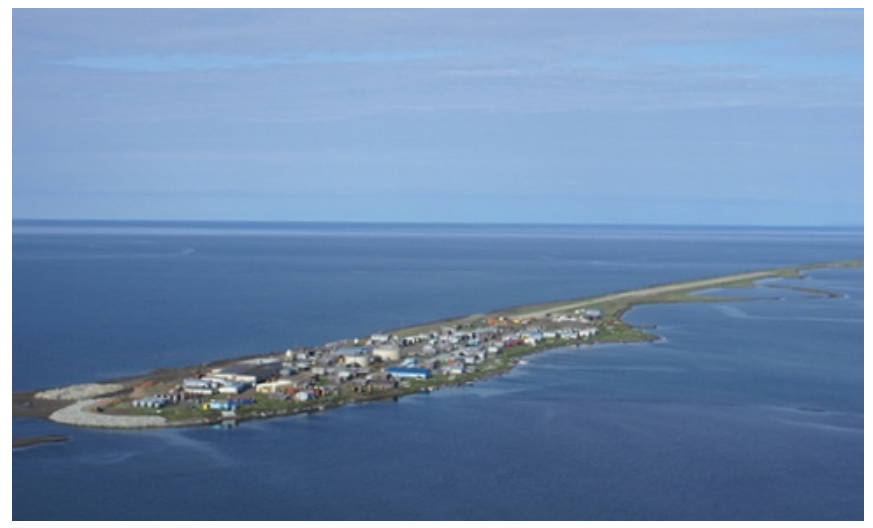

Figure 1: Kivalina, showing coastal protection measures. Source: Flickr/Uscgpress. 
According to the U.S. Global Change Research Program's National Assessment report on climate change, Alaska's climate has warmed an average $4^{\circ} \mathrm{F}\left(2^{\circ} \mathrm{C}\right)$ since the 1950 s, and as much as $7^{\circ} \mathrm{F}\left(4^{\circ} \mathrm{C}\right)$ in the interior during winter, with sea ice thinning $40 \%$ since the 1960 s. The lack of sea ice makes coastlines vulnerable to erosion and flooding (NAS 2000). In 2003, the Government Accountability Office reported that most of Alaska's more than 200 Native villages were affected to some degree by flooding and erosion, with 31 facing imminent threats and four requiring relocation, including Kivalina (GAO 2003). After the 2003 GAO report, Congress called for the Army Corps of Engineers to assess the threat and estimate relocation costs for seven at-risk coastal villages, again including Kivalina, and to carry out an Alaska erosion baseline study, to coordinate, plan, and prioritize responses to erosion in Alaska Native village communities. The Corps completed the assessment of the seven villages in 2006 (USACE 2006a), and the erosion report in 2009 (USACE 2009). In the 2006 examination, the Corps estimated that the village of Kivalina, as well as Newtok and Shishmaref, would be lost to erosion in 10 to 15 years, estimating the cost of relocation at US\$80 million to US\$200 million for each village (USACE 2006a).

Kivalina residents first noted coastal erosion in the 1950s, and voted to begin a relocation process in 1992 (Mitchell 2007). As they tried to move, however, they found that there was no government body to assist communities with this process, and that most disaster programs and funds are available only after disaster occurs, not before. Their fragile situation became dangerous in 2004, when a large storm hit the tiny island. Due to the thinning of sea ice from warming fall temperatures, Kivalina's shoreline was vulnerable to erosion, and a large chunk of the coastline abruptly crumbled into the sea. Another big storm hit in 2005, taking more land and putting several homes in danger. Government reports later estimated the village had experienced between 70 to 80 feet of erosion from the storms, in some areas exposing the permafrost and further destabilizing the shoreline (USACE 2007).

Kivalina was declared a disaster area and the Federal Emergency Management Agency (FEMA) provided sandbags to help prevent further erosion. It was clear that more than sacks were needed, however, and Congress passed Section 117 in the 2005 Consolidated Appropriations Act, which allowed the Army Corps to carry out storm damage protection projects for Alaska Native Villages at full federal expense, waiving a normal cost-sharing requirement (GAO 2009). A barrier was constructed soon after by a private Homeland Security contractor, and failed the day before its inauguration, leaving the village temporarily unprotected.

After another storm and an evacuation in 2007, the Army Corps approved construction of a large rock revetment project for Kivalina. The revetment was designed to be 3,200 feet (975 metres) long, and completed over a period of approximately ten years (USACE 2007). However funding for the wall was only secured for 1,600 feet (488 metres) on the oceanside of the village, where the fuel tanks had been relocated (Figure 2). In 2009, Section 117 was rescinded for unknown reasons (GAO 2009) and funding lost, although the wall was eventually completed.

Despite the revetment, community relocation remains necessary. Yet no agency has complete responsibility for Kivalina's situation, and there are few policies and protocols in existence to assist it. Instead, there are multiple agencies with different authorities, norms, and responsibilities, which Kivalina residents must try to bring together through their own efforts.

Kivalina was able to initiate an Army Corps of Engineers master plan to determine the possibilities for relocation - an environmental impact report separate from the 2006 erosion report that would help the village determine the technical feasibility of relocating to a new location. Such a report would also help authorize and facilitate federal assistance, documenting whether Kivalina's relocation meets the requirements for federally sponsored projects under the National Environmental Policy Act (NEPA). The master plan was undertaken by the Army Corps but contracted out to Tryck Nyman Hayes (TNH), an engineering, construction, and technical services organization based in Alaska (USACE 2006b). After receiving the contract, TNH was acquired by URS Corporation, a private engineering and technical services corporation that has been granted many Homeland Security contracts.

Kivalina had voted in 2000 to pursue relocation to Kiniktuuraq, a site a mile southeast of the village on the Chukchi Sea coastline that had long been used by residents as a camping ground during hunting trips. TNH/URS evaluated six sites in its master plan for Kivalina's relocation, among them Kiniktuuraq, and concluded this site was "vulnerable to erosion and must be armored using armor rock and riprap" (USACE 2006b: 77). This frustrated Kivalina residents, as it conflicted with their traditional knowledge of the area, as well as data from the National Oceanic and Atmospheric Administration (NOAA). The Army Corps requires, however, for FEMA to delineate the floodplain (the potential for an area to be subject to flooding), not NOAA, making NOAA's data and Kivalina's traditional knowledge immaterial. If the site were declared vulnerable to erosion, it would then require long-term protection by sand nourishment to qualify for government assistance and insurance, raising the costs of relocation significantly. 


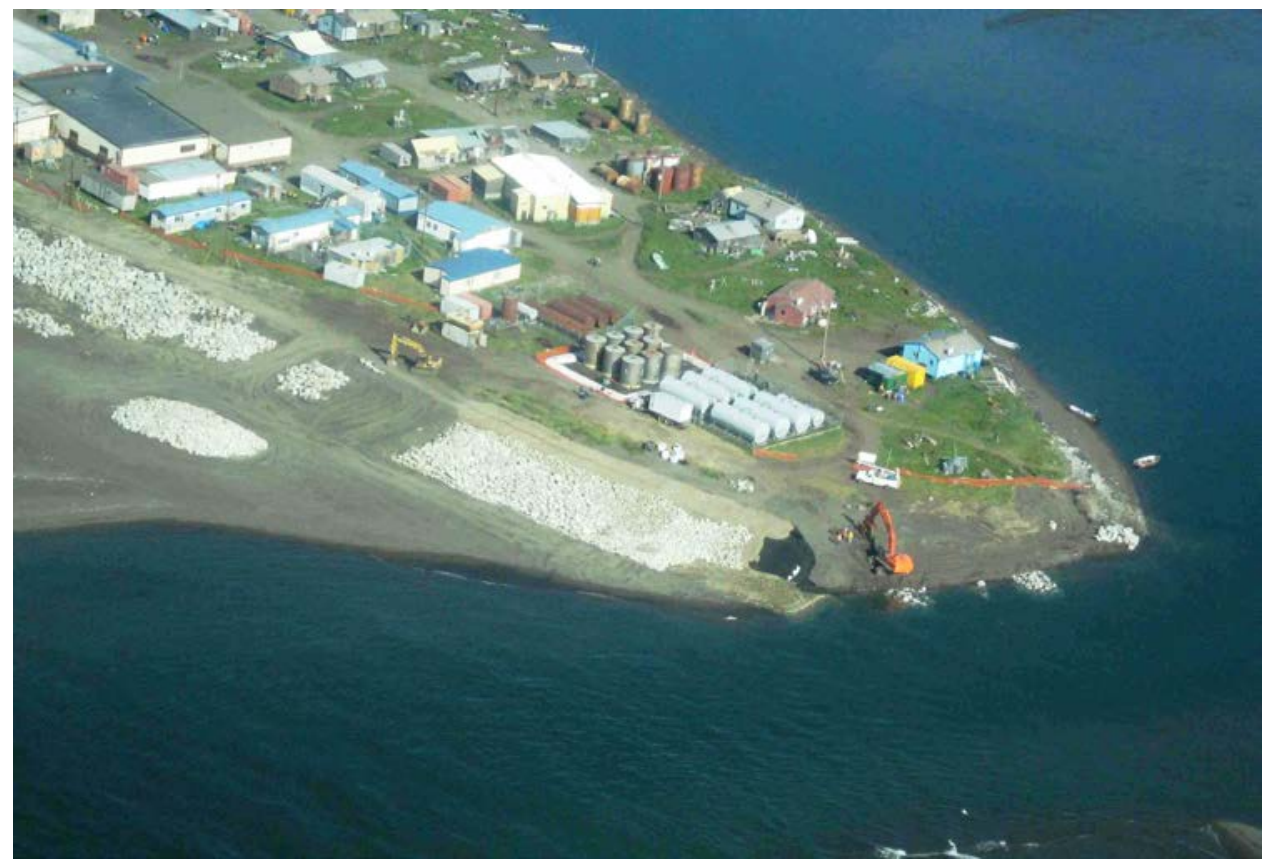

Figure 2: Rock revetment project under construction, Kivalina 2008. Source: author

Disagreement over a new site has put on hold an already painfully slow process, and is jeopardizing funding not only for relocation, but also emergency assistance. Due to the high costs associated with construction in such remote areas, building of an evacuation road and evacuation site on higher ground would ideally lead toward the new preferred location. Uncertainty over the new site also puts construction of a badly needed island evacuation road into question, as it would go toward the new site.

\section{Difficulties facing Kivalina}

\section{Lack of lead entity}

While there are multiple problems facing Kivalina in its search for relocation, many of these are rooted in the lack of a responsible government body. This has been a long, ongoing problem voiced by Kivalina residents, such as tribal administrator Colleen Swan: "There wasn't anyone we could talk to about climate change and what it was doing to our environment. There's no agency in the federal government that deals with climate change" (personal interview, August 7, 2008). Without a designated federal agency in charge of relocation or climate change, there is no agency responsible for Kivalina's situation.

According to Allen Chan, who worked on a 2009 Government Accountability Office report assessing the situation of Alaska Natives and climate change, a lead agency could help communities with navigating the maze of available government assistance: "One of the advantages of a lead federal agency is that if there are multiple programs available, [the agency] could better coordinate the funding" (personal interview, July 28, 2009).

Kivalina City Administrator Janet Mitchell also voiced the opinion that a designated, responsible agency would help: "[the relocation] would move faster if we had [a lead entity], someone focused on relocation" (personal interview, August 25, 2008). When asked who she would prefer, Mitchell replied: "A group of people from different agencies. That would make it more powerful. Everyone would have a voice. Including Kivalina."

In the absence of a lead entity, agencies individually prioritize assistance to villages on the basis of their own protocols and criteria. Trying to get these different agencies to work together can be challenging. According to Patricia Opheen, Chief of Engineering for the Army Corps in Alaska: "Any agency that has funding is reluctant to go forward with any piece of the overall plan without knowing if everyone is working toward the same plan" (personal interview, September 4, 2009). Opheen's statement highlights the difficulty of institutional action in cases involving inter-organizational contexts without an overarching or centralized structure (Clarke 1999). If there are problems with just one agency, the entire relocation process can be put on hold, as evidenced by the reluctance of agencies to assist Kivalina with evacuation roads and relocation to their preferred relocation site without a FEMA delineation of a floodplain in the area. 
Further, agency criteria for tribal assistance varies, and does not necessarily reflect the villages in greatest danger. The Corps has identified 26 priority communities in its 2009 erosion assessment, based upon factors such as the level of threat to critical infrastructure, and human health and safety, among other factors (USACE 2009). Although the Corps identified at-risk communities and assessed erosion threats, there is no lead federal entity to prioritize and coordinate assistance using this information. Further, the Corps' assessment does not include risks from flooding.

\section{Need for strengthened risk mitigation and relocation measures}

As stated by Janet Mitchell: "The word relocation doesn't exist on the federal level, and I doubt that it exists at the state level" (personal interview, August 25, 2008). At the federal, state, and tribal levels, there is a lack of clearly defined risk mitigation protocols and resettlement procedures that would trigger more pro-active measures to ensure Kivalina's safety.

Instead, government agencies must act according to their procedures and in their area of responsibility, even if they know this will be insufficient to mitigate danger for Kivalina. For the erosion assessment, the final report issued by the Corps notes that flooding is as severe a problem as erosion, and concludes that an assessment of flooding should be carried out, to offer a more comprehensive understanding of the threats that Alaska Native villages face (USACE 2009). The Corps did not assess flooding threats, however, because Corps officials believed they lacked the authority for such an assessment: while the 2004 Congressional report that led to the Corps's erosion study refers to both flooding and erosion threats, the specific language calls for an Alaska erosion baseline study. Corps officials therefore interpreted this language to mean that they were only authorized to conduct a baseline assessment of erosion threats (GAO 2009). In other words, the Army Corps felt unable to move beyond its prescribed boundaries to offer a more holistic assessment of the problems facing Alaska Natives (March and Olsen 1986).

Without a comprehensive assessment of flooding, agencies lack federally recognized and approved information on the problems facing Alaska Native villages, limiting the options available for assistance. Indigenous knowledge, meanwhile, is often treated as anecdotal and non-scientific (Bielawski 1996) and thus ineligible for meeting NEPA requirements, as well as FEMA flood plain insurance.

\section{Policies for disaster management rather than risk mitigation}

Federal programs to help threatened communities prepare for, and recover from disasters are limited and unavailable to many Alaska Native villages. While FEMA administers some flood insurance, disaster recovery programs and grants for disaster mitigation and preparedness, small and remote Alaska villages often fail to qualify.

Ironically, many villages cannot participate in the National Flood Insurance Program due to the lack of systematic federal studies on flooding in the area, and thus no FEMA delineation of a floodplain for qualification into the program. FEMA administers mitigation grants, but most villages lack approved mitigation plans, particularly since FEMA distributes most of its mitigation grants on the basis of the costeffectiveness of the proposed project. With low populations and high construction costs in rural Alaska, Alaska Native village mitigation plans are often not seen as cost-effective (GAO 2009). Eligibility for FEMA's two disaster recovery programs and also the Hazard Mitigation Grant Program is generally limited to areas that have been declared federal disasters. Since many of the villages are facing gradual erosion problems and have not received a declared disaster designation, they do not qualify for these programs (GAO 2009).

Few federal disaster declarations have been made for flooding and erosion problems before rapidonset disasters occur (GAO 2009). Thus even though climate changes are bringing unprecedented problems, FEMA is relying upon existing policies and procedures (March and Olsen 1986), many of which are only made available after an institutionally recognized emergency (Vaughan 2002), setting up the potential for disaster (Turner 1976; Turner and Pidgeon 1997; Vaughan 2002).

\section{Private contractors that are unaccountable to the public}

According to Janet Mitchell, the village had no say in the initial sea barrier project that failed the day before its inauguration: "Who would do it was pretty much out of our hands, they were contracted by the Army Corps" (personal interview, August 25, 2008) A similar experience was reported by Colleen Swan: "the final decision for the rock revetment goes to the Corps. We had absolutely no voice for the project that came in 2006. The wire baskets, filled with sand, and no bottom. One on top of the other, no bottom, and the waves just sucked out the sand from the bottom" (personal interview, August 7, 2008). With the initial sea barrier, the use of a private contractor ignored community input and ultimately put them in further danger. Villagers perceived the government as unreliable (Freudenburg 1993), eroding their trust in government agencies and procedures (Sapp et al. 2009). A similar experience was felt when the master plan was contracted to URS Corporation, which has yet to respond to Kivalina's request to reconsider its data on relocation sites and costs in its master report for the village. This has put the entire relocation on hold. 


\section{Lack of international assistance}

As stated, there is no relocation policy at the national or international level. Further, while the UNFCCC supports adaptation measures like capacity-building for preventive measures, planning, preparedness for and management of disasters relating to climate change, this support cannot be accessed by Inuit populations like Kivalina, because they are non-State actors and not party to the treaties (Budreau and McBean 2007). Kivalina is located within a developed nation, but this does not mean it is receiving the full assistance it needs. The community's efforts to obtain relocation costs through the U.S. courts failed in 2009 and the population remains on the island (Shearer 2011).

\section{Conclusion}

This article has explored how the lack of comprehensive policies for displacement and relocation, and restriction of adaptation assistance at the international level, can heighten community vulnerability to climate change. In Kivalina, we can see how the U.S. agencies involved in relocation are unable to develop new procedures and to address holistically an unprecedented problem: the relocation of Alaska Native villages like Kivalina due to coasted erosion and flooding linked to climate change. Without clear relocation policies, the agencies involved have relied upon established protocols and standardized procedures for disaster management and coastal protection, even though these are insufficient to address the full scope of the problem.

Agencies like FEMA are primarily triggered to action only after 'institutionally recognized' disasters, often preventing them from taking action on earlier signals of concern and danger. By the time emergency hits Kivalina, it may be too late, since the village has limited means of evacuation - all-terrain vehicles, small boats, and planes - which could be inadequate or unusable in the event of a large storm. Thus Kivalina is left in an administrative orbit, with residents made to work their way through numerous government programs and procedures.

But these deficiencies can be minimized. Expanding the flexibility of agencies to assess and deal with the problems affecting Kivalina would help bring about more pro-active and responsive implementation. Further, agency assessments could help lead to the institutionalization more widely of more clearly defined protocols for assisting communities in danger from climate changes and hazards, and in need of relocation. Such protocols could help transform perfunctory and ongoing bureaucratic processes into more effective and efficient policy.

Such innovations and flexibility, in turn, could help inform a clearly defined policy specifically designed to assist those displaced by climate change, such as 'climigration.' Standards would be set in place to determine when in-situ adaptation is no longer possible, and thus a community no longer needs disaster management, but instead needs relocation (Bronen 2009). This would ideally involve the input of affected communities, who are best situated to express when circumstances are reaching an unmanageable, emergency stage. The Kivalina case suggests that relocation planning and disaster management efforts, and the agencies responsible, should be more closely linked, and part of a broader shift toward communitybased risk mitigation, to help prevent disasters before they occur. Relocation policies would also benefit from the designation of a responsible government agency, so that communities are not left to deal with the process on their own.

\section{References}

Agarwal, A. and S. Narain. 1991. Global warming in an unequal world: a case of environmental colonialism. Earth Island Journal 268 (5215): 1-34.

Beamish, T. 2002. Waiting for crisis: regulatory inaction and ineptitude and the Guadalupe Dunes oil spill. Social Problems 49: 150-177.

Bielawski, E. 1996. Inuit indigenous knowledge and science in the Arctic. in L. Nader (ed.) Naked science: anthropological inquiry into boundaries, power, and knowledge. New York: Routledge. Pp. 216-227.

Bierbaum, R., J.P. Holdren, M. MacCracken, R.H. Moss, P.H. Raven and H.J. Schellnhuber. 2007. Confronting climate change: avoiding the unmanageable and managing the unavoidable. Research Triangle Park, N.C., and Washington, D.C.: Report by the Scientific Expert Group on Climate Change for Sigma Xi and the United Nations Foundation.

Bronen, R. 2008. Alaskan communities rights and resilience. Forced Migration Review 3: 30-32.

Bronen, R. 2009. Forced migration of Alaskan Indigenous communities due to climate change: creating a human rights response. in T. Afifi and J. Jager (eds.) Linking environmental change, migration and social vulnerability. New York: Springer.

Budreau, D. and G. McBean. 2007. Climate change, adaptive capacity and policy direction in the Canadian North: Can we learn anything from the collapse of the east coast cod fishery? Mitigation and Adaptation Strategies for Global Change 12: 1305-1320.

Cardona, O. 2003. The need for rethinking the concepts of vulnerability and risk from a holistic perspective: a necessary review and criticism for effective risk management. in G. Bankoff, G. Frerks, and D. Hilhorst (eds.) Mapping vulnerability: disasters, development and people. London: Earthscan.

Carus, F. 2011. Alaskan community revives legal bid for global warming damages. The Guardian. 30 November 2011 [accessed 20 July, 2012] 
Chance, N. 1990. The Iñupiat and Arctic Alaska: an ethnography of development. Fort Worth, TX: Holt Rinehart \& Winston.

Christoplos, I., J. Mitchell, and A. Liljelund. 2001. Re-framing risk: the changing context of disaster mitigation and preparedness. Disasters 25: 185-198.

Clarke, L. 1999. Mission improbable: using fantasy documents to tame disaster. Chicago: University of Chicago Press.

Eichelberger, L. 2012. Sustainability and the politics of calculation: technologies of 'safe water,' subjectmaking, and domination in Alaska. Journal of Political Ecology 19:145-161.

El-Hinnawi, E. 1985. Environmental refugees. United Nations Environment Programme report. Nairobi: UNEP.

Ford, J.D. 2009. Dangerous climate change and the importance of adaptation for the Arctic's Inuit population. Environmental Research Letters 4: 024006.

Freudenburg, W.R. 1993. Risk and recreancy: Weber, the division of labor, and the rationality of risk perceptions. Social Forces 71: 909-932.

GAO. 2003. Alaska Native villages: most are affected by flooding and erosion, but few qualify for federal assistance. Government Accountability Office Report GAO-04-142.

GAO. 2009. Alaska native villages: limited progress has been made on relocating villages threatened by flooding and erosion. Government Accountability Office Report GAO-09-551.

Gunewardena, N., M. Schuller and A. de Waal. 2008. Capitalizing on catastrophe: neoliberal strategies in disaster reconstruction. Lanham, MD: Altamira Press.

Gusfield, J.R. 1989. Constructing the ownership of social problems: fun and profit in the welfare state. Social Problems 36: 431-441.

Hawkins, K. and J.M. Thomas. 1989. Making regulatory policy. Pittsburgh: University of Pittsburgh Press.

Kelman, I. 2010. Hearing local voices from small island developing states for climate change. Local Environment 15: 605-619.

LaPorte, T.R. 1996. High reliability organizations: unlikely, demanding and at risk. Journal of Contingencies and Crisis Management 4: 60-71.

LaPorte, T.R. and P.M. Consolini. 1991. Working in practice but not in theory: theoretical challenges of high-reliability organizations. Journal of Public Administration Research and Theory 1: 19-48.

Lavell, A. 1998. Decision making and risk management. Paper prepared for and presented at the Conference on Furthering Cooperation in Science and Technology for Caribbean Development. Port of Spain, Trinidad: http://www.la-red.org/public/articulos/1998/dmrm/dmrm1998_mar-1-2002.pdf, [accessed April 3, 2012].

March, J.G. and J.P. Olsen. 1986. Garbage can models of decision making in organizations. in J. March and R. Weissinger-Baylon (eds.) Ambiguity and command: organizational perspectives on military decision making. New York: HarperCollins College.

McCright, A.M. and R.E. Dunlap. 2000. Challenging global warming as a social problem: an analysis of the conservative movement's counter-claims. Social Problems 47(4):499-522.

McCright, A.M. and R.E. Dunlap. 2003. Defeating Kyoto: the conservative movement's impact on US climate change policy. Social Problems 50: 348-373.

Mearns, R. and A. Norton. 2010a. Equity and vulnerability in a warming world. In R. Mearns and A. Norton (eds.) Social dimensions of climate change: equity and vulnerability in a warming world. Washington, DC: World Bank Publications. Pp. 1-46.

Mearns, R. and A. Norton (eds.). 2010b. Social dimensions of climate change: equity and vulnerability in a warming world. Washington, DC: World Bank Publications.

Mitchell, Janet. 2007. Erosion. www.kivalinacity.com, [accessed August 19, 2010].

Morrissey, J. 2012. Rethinking the 'debate on environmental refugees': from 'maximilists and minimalists' to 'proponents and critics'. Journal of Political Ecology 19: 36-49.

NAS. 2000. Climate change impacts on the United States: the potential consequences of climate variability and change. Overview: Alaska. National Assessment Synthesis Team, U.S. Global Change Research Program. http://www.gcrio.org/NationalAssessment/overpdf/overview.html, [accessed August 19, 2010].

O'Brien, G., P. O'Keefe, J. Rose and B. Wisner. 2006. Climate change and disaster management. Disasters 30: 64-80.

Pearce, L. 2003. Disaster management and community planning, and public participation: how to achieve sustainable hazard mitigation. Natural Hazards 28: 211-228.

Raworth, K. 2008. Climate wrongs and human rights: putting people at the heart of climate-change policy. Oxfam Briefing Paper 117. Oxfam International.

Roberts, J.T. 2001. Global inequality and climate change. Society and Natural Resources 14: 501-509.

Roberts, J.T. and B.C. Parks. 2006. A climate of injustice: global inequality, North-South politics, and climate policy. Boston: MIT Press.

Roth, L. 1992. Media and the commodification of crisis. in B.D.M. Raboy (ed.) Media, crisis, and democracy: mass communication and the disruption of social order. London: Sage. Pp. 144-161. 
Sapp, S.G., C. Arnot, J. Fallon, T. Fleck, D. Soorholtz, M. Sutton-Vermeulen and J.J.H. Wilson. 2009. Consumer trust in the US food system: an examination of the recreancy theorem. Rural Sociology 74: 525-545.

Shearer, C. 2011. Kivalina: a climate change story. Chicago: Haymarket Books.

Tierney, K. 2003. Disaster beliefs and institutional interests: recycling disaster myths in the aftermath of 911. Research in Social Problems and Public Policy 11: 33-51.

Turner, B. 1976. The organizational and interorganizational development of disasters. Administrative Science Quarterly 21: 378-397.

Turner, B., and N. Pidgeon. 1997. Man-made disasters. Oxford, UK: Butterworth-Heinemann.

UNDP. 2007. Fighting climate change: human solidarity in a divided world. United Nations Development Programme Human Development Report 2007/2008. Pp 1006-26.

USACE. 2006a. Alaska village erosion technical assistance program: an examination of erosion issues in the communities of Bethel, Dillingham, Kaktovik, Kivalina, Newtok, Shishmaref, and Unalakleet. Army Corps of Engineers Report.

USACE. 2006b. Kivalina relocation master plan. Army Corps of Engineers Report.

USACE. 2007. Environmental assessment: Section 117 expedited erosion control project for Kivalina, Alaska. U.S. Army Corps of Engineers Environmental Assessment Report.

USACE. 2009. Alaska baseline erosion assessment. U.S. Army Corps of Engineers Study Findings and Technical Assessment Report.

Vaughan, D. 2002. Signals and interpretive work: the role of culture in a theory of practical action. in K. Cerulo (ed.) Culture in mind: toward a sociology of culture and cognition. New York: Routledge. Pp. 28-54.

Warner, K. 2010. Global environmental change and migration: governance challenges. Global Environmental Change 20: 402-413.

Weick, K.E. 1995. Sensemaking in organizations. Thousand Oaks: Sage Publications, Inc.

\title{
INTERVIEWS
}

Chan, A., personal interview, July 28, 2009

Mitchell, J., personal interview, August 25, 2008

Opheen, P., personal interview, September 4, 2009

Swan, C., personal interview, August 7, 2008

\begin{abstract}
Although much research on climate change has focused on its disproportionate effects on the Global South, communities-particularly indigenous populations-within "developed" nations in the Global North can also face significant effects and inadequate assistance. One example is the native village and city of Kivalina in northwest Alaska. Through a case study of Kivalina, this article explores the gaps in U.S. policy for relocating Alaska Natives due to the effects of climate change. There is currently no policy in placewithin the United States or internationally_for the resettlement of communities displaced by climate change. And in the United States there is no lead agency in charge of relocating displaced communities, despite several U.S. government reports stating that at least four Alaska Native villages, including Kivalina, must be resettled due to warming Arctic temperatures and erosion. This leaves government agencies in charge of assisting villages like Kivalina, such as the Federal Emergency Management Agency and the Army Corps of Engineers, who are responsible for helping ensure Kivalina's safety but are not empowered to innovate new procedures and holistically address what is an unprecedented problem: climate change. This has left Kivalina in what is termed here an administrative orbit, with residents made to work their way through a patchwork of various government programs and procedures that are time-consuming and often insufficient. In exploring these intra-national inequities, this article examines how a protocol specifically designed for those displaced by climate change, such as "climigration," could be merged with existing government efforts around emergency management to help prevent disasters before they occur, and to protect at-risk communities like Kivalina.
\end{abstract}

Keywords: Disaster management; Alaska: environmentally induced migration; indigenous studies; resilience; displacement; relocation. 


\section{Résumé}

Bien que la majorité de la recherche sur le changement climatique a mis l'accent sur ses effets disproportionnés sur les pays du Sud, les communautés autochtones dans les pays dits développés dans le Nord mondiale peuvent aussi être confrontés des effets significatifs et l'assistance inadéquate. Un exemple est le village de Kivalina au nord-ouest de l'Alaska, États-Unis. Cet article explore les lacunes dans la politique américaine pour la relocalisation autochtones de l'Alaska en raison des effets du changement climatique. Il n'existe actuellement aucune politique américaine ou internationale pour la réinstallation des communautés déplacées par le changement climatique. Et aux Etats-Unis, il n'existe pas d'organisme principal en charge de réinstaller les communautés déplacées. Ceci malgré le fait que plusieurs rapports du gouvernement américain a identifié quatre villages autochtones de l'Alaska (y compris les Kivalina) qui doivent être réinstallés en raison du réchauffement des températures de l'Arctique et l'avancé d'érosion du littoral. Plusieurs organismes gouvernementaux sont donc en charge d'aider les villages comme Kivalina, tels que la Federal Emergency Management Agency et l'Army Corps of Engineers. Ils sont responsables de contribuer à assurer la sécurité des habitants Kivalina, mais ils n'ont pas le pouvoir à innover, et à aborder tous les aspects des impacts du changement climatique. Cela a laissé Kivalina dans une «orbite administrative». Les résidents ont à travailler dans un patchwork de divers programmes gouvernementaux et des procédures qui prennent du temps et sont souvent insuffisants. En explorant ces inégalités intranationales, cet article examine comment un protocole spécialement conçu pour les personnes déplacées par le changement climatique, tels que «climigration», pourrait être fusionné avec les efforts actuels du gouvernement autour de la gestion des urgences pour aider à prévenir les catastrophes avant qu'elles ne surviennent, et de protéger les communautés à risque, comme Kivalina.

Mots-clés: gestion des catastrophes, la migration induite par l'environnement, les études autochtones; la résilience, le déplacement, la réinstallation.

\section{Resumen}

Aunque buena parte de la investigación sobre el cambio climático se ha enfocado en sus efectos desproporcionados sobre los países menos desarrollados (Países del Sur), las comunidades ubicadas en los países "desarrollados" - particularmente las poblaciones indígenas- en los Países del Norte también pueden enfrentar efectos significativos y una ayuda inadecuada. Un ejemplo de esto es la población indígena y ciudad de Kivalina en el noroeste de Alaska. Mediante este estudio de caso sobre Kivalina, este ensayo explora las diferencias en la política estadounidense para reubicar a los indígenas de Alaska debido a los efectos del cambio climático. Hoy en día no se ha establecido una política- ni dentro de los Estados Unidos ni a nivel internacional- para el reasentamiento de las comunidades desplazadas por el cambio climático. No existe una dependencia principal en los Estados Unidos encargada de reubicar a las comunidades desplazadas, a pesar de varios reportes del gobierno de los Estados Unidos indicando que por lo menos cuatro poblados indígenas de Alaska, incluyendo Kivalina, deben reubicarse debido al calentamiento de las temperaturas Árticas y a la erosión. Esto deja a las dependencias gubernamentales a cargo de ayudar a poblaciones como Kivalina, como la Agencia Federal para el Manejo de Emergencias (FEMA, por sus siglas en inglés) y el Cuerpo de Ingenieros del ARMY, quienes son responsables de garantizar la seguridad de Kivalina pero no tienen la suficiente autoridad para crear nuevos procedimientos y tratar holísticamente lo que es un problema sin precedentes: el cambio climático. Esto ha colocado a Kivalina en lo que aquí se conoce como una órbita administrativa, donde los residentes tienen que buscar la manera a través de una mezcla de varios programas y procedimientos gubernamentales que conllevan demasiado tiempo y a menudo no son suficientes. Al explorar estas desigualdades transnacionales, este estudio examina la manera en que un protocolo como la "climigración", que fue diseñado específicamente para aquellos desplazados por el cambio climático, puede combinarse con esfuerzos gubernamentales que ya existen para el manejo de emergencias con el fin de ayudar a prevenir desastres antes de que ocurran y proteger a comunidades en riesgo como Kivalina.

Palabras Clave: Manejo de desastres; Alaska: migración causada por el medio ambiente; estudios indígenas; resistencia, desplazamiento; reubicación. 